\title{
MEKANISME REKRUTMEN PARTAI POLITIK DALAM PENETAPAN CALON LEGISLATIF DI KABUPATEN HALMAHERA UTARA
}

(Studi Kasus di DPC PDIP Kabupaten Halmahera Utara 2014)

*Adrian Lopak*

*Frets A. Goraph*

\begin{abstract}
ABSTRAK
Partai politik di Indonesia merupakan institusi yang di anggap penting dalam membangun sistem politik demokrasi di Indonesia. Rekrutmen yang dilakukan partai politik merupakan wujud mencari kader-kader terbaik partai guna maju sebagai calon pada pemilihan legislative di Halmahera Utara Tahun 2014. Kebijakan partai PDIP untuk merekrut kader merupakan amanat peraturan partai politik dan AD-ART tersebut yang patut dilaksanakan. Dengan demikian diharapkan mampu memunculkan wakil-wakil rakyat yang terbaik pada pemilihan legislative 2014 di Kabupaten Halmahera Utara.
\end{abstract}

Tujuan penelitian ini untuk mengetahui bagaimana mekanisme rekrutmen yang dilakukan oleh Partai DPC PDI-Perjuangan Halmahera Utara. Adapun mekanisme rekrutmen calon anggota Legislatif harus melalui proses; Pendaftaran, Penjaringan, Penyaringan, dan seleksi administrasi. Kader partai harus paham tentang ideologi dan peraturan yang terkandum dalam partai PDIP tersebut.

Studi ini menggunakan pendekatan penelitian kualitatif. Metode pengumpulan data dilakukan dengan dua cara yaitu wawancara mendalam dan kajian dokumentasi. Guna memperoleh data penelitian maka dilakukan wawancara dengan orang-orang kunci yang mengalami dan merasakan bagaimana rekrutmen dilakukan. Kemudian data penelitian dijelasakan dan dianalisis untuk mencari makna dalam penelitian ini.

Rekrutmen partai politik memberikan gambaran jelas bagaimana calon legislative mengikuti tahapan-tahapan pendaftaran, penjaringan, penyaringan dan sampai pada penetapan calon anggota legislative. Namun dilematis ketika sampai pada penentuan calon tetap legislative partai politik PDI-P, karena pada titik ini terjadi pertarungan kepentingan politik individu untuk menjadi calon legislative.

Kata kunci: Mekanisme Rekrutmen, Partai Politik, dan Calon Legislatif 


\section{ABSTRACT}

Political parties in Indonesia is an institution that is considered important in modern democracy system. By because it, political parties are obliged to conduct recruitment for prospective members of the Legislature who later cadres will be placed parliamentary party. PDIP Party In the face of the 2014 election has a policy to implement Legislative Candidate Recruitment Mechanism. Thus expected to bring representatives of the best in the 2014 elections, at the level of North Halmahera district legislature.

Starting from the backdrop, researchers aim to determine the mechanism of recruitment conducted by the PDI-P Party of North Halmahera. The regulation states that the mechanism Recruitment Legislative Candidates must go through the registration process, networking, Filtering, and Test administration. Psychological test. Assignment and understanding of the ideology that contained in the PDIP party.

It can be concluded, that the members of the Legislative Candidates must follow the rules that exist in the party PDI-P. Start of the registration process, networking, and filtering.

While obstaclic experienced by DPC PDIP Party in recruiting Legislative contained in the screening process because this process into a discussion that specifies the names of the candidates according to the criteria of the PDI-P party.

Keywords: Registration, Networking, Screening and Determination Legislative Candidates. 


\section{Latar Belakang Masalah}

Berdasarkan Undang-undang Nomor 08 Tahun 2012 tentang Pemilihan Umum Anggota Dewan Perwakilan Rakyat, Dewan Perwakilan Daerah, dan Dewan Perwakilan Rakyat Daerah, didalamnya juga mengatur tentang mekanisme rekrutmen politik para calon legislative. Dalam peraturan tersebut juga mengatur tugas dan tangunggjawab penyelenggara pemilu agar pemilihan legislative bisa berjalan jujur dan adil. Kemudian Komisi Pemilihan Umum (KPU) berdasarkan pasal 1 tentang ketentuan umum pada undang-undang disebutkan bahwa KPU merupakan lembaga yang bersifat nasional, tetap, dan mandiri untuk menyelenggarakan Pemilu. Pencalonan anggota legislatif merupakan salah satu proses dan tahap penting dalam pemilihan umum untuk mencari CALEG yang berintegritas baik.

Dalam praktik pemilu di Indonesia, pemilih dilihat hanya sebagai objek politik dan bukan subjek politik sehingga ketika menjadi anggota Dewan Perwakilan Rakyat Daerah (DPRD), seringkali pemilih tidak merasa terwakili aspirasi dan kepentingannya oleh para anggota legislative. Rekrutmen politik adalah proses pengisian jabatan-jabatan pada lembaga-lembaga politik termasuk partai politik dan administrasi atau birokrasi oleh orang-orang yang akan menjalankan kekuasaan politik (Suharno, 2004: 117).

Kontestasi politik pada Tahun 2014 Partai PDI Perjuangan Kabupaten Halmahera Utara yang mengikuti pemilihan legislative sebagai berikut: Dapil I, 6 (enam) orang diantaranya perempuan 2 (dua) orang dan laki-laki 4 (empat) orang, Dapil II, 11 (sebelas) orang diantaranya laki-laki sebanyak 7 (tujuh) orang dan perempuan sebanyak 4 (empat) orang sedangkan Dapil III, 7 (tujuh) orang yaitu laki-laki.

Dengan demikian pada pemilihan umum legislative Partai politik PDIP Kabupaten Halmahera Utara tahun 2014 mengalami masalah dalam hal perbedaan kursi. Pada tahun 2009 pemilihan anggota legislative Partai PDIP mendapatkan 3 (tiga) kursi, sedangkan ditahun 2014 Partai PDIP hanya mendapatkan 2 (dua) kursi, diantaranya yang berhasil menduduki jabatan 
anggota legislative adalah Joel Wogono $\mathrm{SH}, \mathrm{MH}$ sebagai calon dapil II, dan Ibu Inggrid Paparang SE, dari calon Dapil I. Pada titik ini terjadi penurunan perolehan jumlah kursi 1 (satu) orang menjadi anggota DPRD Kabupaten Halmahera Utara itu artinya ada kemungkinan terjadi kesalahan pada proses rekrutmen calon maupun pada proses penentuan calon anggota DPRD. Studi ini menjadi penting guna mencari tahu dan mengungkap bagaimana proses rekrutmen partai politik PDIP cabang Tobelo dalam penentuan calon DPRD.

\section{Landasan Teori}

Dalam studi ini peneliti menggunakan kerangka teori Vicky Randall dan Lars Svasand (2002), sebagai dasar untuk menjelaskan masalah-masalah penelitian guna mencari benang merah antara masalah penelitian dengan teori yang dipakai.

Dalam studi-studi tentang pelembagaan partai politik ditemukan bahwa proses pemantapan partai politik baik secara struktural dalam rangka mempolakan perilaku maupun secara kultural dalam mempolakan sikap atau budaya (the process by wich the pary becomes established in terms of both integrated patterns on behavior and of attitudes and culture).

Proses pelembagaan partai politik ini mengandung dua aspek, yaitu aspek internal-eksternal, dan aspek struktural-kultural. Bila kedua dimensi ini dipersilangkan, maka akan tampak sebuah tabel empat sel, yaitu;

1. Dimensi kesisteman (systemness) suatu partai sebagai hasil persilangan aspek internal dengan structural.

2. Dimensi identitas nilai (value infusion) suatu partai sebagai hasil persilangan aspek internal dengan kultural,

3. Dimensi otonomi suatu partai dalam pembuatan keputusan (decisional autonomy) sebagai hasil persilangan aspek eksternal dengan struktural,

4. Dimensi pengetahuan atau citra publik (reification) terhadap suatu partai politik sebagai persilangan aspek eksternal dengan kultural

\begin{tabular}{|l|l|l|}
\hline Dimensi Kepartaian & \multicolumn{1}{|c|}{ Internal } & \multicolumn{1}{c|}{ Internal } \\
\hline Struktural & Kesisteman & Otonomi Keputusan \\
\hline Kultural & Identitas Nilai & Citra pada Publik \\
\hline
\end{tabular}




\section{Dimensi Kesisteman Dalam Partai Politik}

Yang dimaksudkan dengan kesisteman adalah proses pelaksanaan fungsifungsi partai politik, termasuk penyelesaian konflik, dilakukan menurut aturan, persyaratan, prosedur, dan mekanisrne yang disepakati dan ditetapkan dalam AD/ART partai politik. Derajad kesisteman suatu partai bervariasi menurut: (a) asal-usul partai politik, yaitu apakah dibentuk dari atas, dari bawah, atau dari atas yang disambut dari bawah; (b) siapakah yang lebih menentukan dalam partai: seorang peminpin partai yang disegani ataukah pelaksanaan kedaulatan anggota menurut prosedur dan mekanisme yang ditetapkan oleh organisasi sebagai suatu kesatuan; (c) siapakah yang menentukan dalam pembuatan keputusan: faksi-faksi dalam partai ataukah partai secara keseluruhan; dan (d) bagaimana partai memelihara hubungan dengan anggota dan simpatisan, yaitu apakah dengan klientelisme (pertukaran dukungan dengan pemberian materi) ataukah menurut konstitusi partai (AD/ART).

\section{Dimensi Identitas Nilai Partai Politik}

Identitas nilai ini berkaitan dengan identitas partai poilitik berdasarkan ideologi atau platform partai, dan karena itu berdasarkan basis sosial pendukungnya, dan identifikasi anggota terhadap pola dan arah perjuangan yang diperjuangkan partai politik tersebut.

Karena ilu derajad identitas nilai suatu partai politik berkaitan dengan (a) hubungan partai dengan kelompok populis tertentu (popular bases), yaitu apakah suatu partai politik mengandung dimensi sebagai gerakan sosial yang didukung oleh kelompok populis tertentu, seperti buruh, petani, kalangan masyarakat tertentu, komunitas agama tertentu, komunitas kelompok etnik tertentu, dan (b) pengaruh klientelisme dalam organisasi, yaitu apakah hubungan partai dengan anggota cenderung bersifat instrumentalis (anggota selalu mengharapkan tangible resources berupa materi dari partai) ataukah lebih bersifat ideologis (anggota mengenal dan mengharapkan partai bertindak berdasarkan identifikasi terhadap ideologi partai). Partai politik yang mempunyai 
basis sosial pendukung yang spesifik niscaya akan memiliki identitas nilai yang jelas.

\section{Dimensi Otonomi Partai Politik}

Derajad otonomi suatu partai politik dalam pembuatan keputusan berkaitan dengan hubungan partai dengan aktor luar partai baik dengan sumber otoritas tertentu (penguasa, pemerintah), maupun dengan sumber dana (pengusaha, penguasa, negara atau lembaga luar) dan sumber dukungan massa (organisasi masyarakat): (a) apakah partai tergantung kepada aktor luar tersebut ataukah hubungan itu bersifat saling tergantung (interdependen), dan (b) apakah keputusan paitai ditentukan oleh aktor luar ataukah hubungan itu berupa jaringan (linkage) yang memberi dukungan kepada partai.

\section{Dimensi Pengetahuan Publik tentang Partai Politik}

Derajad pengetahuan publik tentang partai politik merujuk pada pertanyaan apakah keberadaan partai politik tersebut telah tertanam pada imajinasi publik. Bila keberadaan partai politik tertentu telah tertanam pada imajinasi publik, maka pihak lain baik para individu maupun lembaga akan menyesuaikan aspirasi dan harapan ataupun sikap dan perilaku mereka dengan keberadaan partai politik tersebut. Derajad pengetahuan publik ini merupakan fungsi dari waktu dan kiprah partai tersebut.

Menurut Imawan (1992), seleksi anggota legislatif harus memenuhi syaratsyarat kapabilitas, popularitas dan akseptabilitas. Ketiga syarat ini harus dipadukan.artinya sesorang kandidat harus benar-benar memiliki kemampuan,

Populer di tengah-tengah masyarakat, diterima oleh masyarakat serta terpilih melalui prosedur perwakilan, bukan hanya sekadar ditunjuk. Budiardjo, mendefinisikan rekrutmen politik sebagai proses melalui mana partai politik mencari anggota baru dan mengajak orang yang berbakat untuk berpartisipasi dalam proses politik.

Haryanto (1997) mengatakan ada dua (2)cara untuk melakukan rekrutmen politik yaitu secara terbuka dan secara tertutup. Pertama): Rekrutmen politik terbuka adalah umum semua warga negara yang memenuhi syarat-syarat yang 
ditentukan serta mempunyai bakat, tanpa kecuali mempunyai: a). kesempatan yang sama untuk menduduki jabatan politik maupun jabatan pemerintahan. Kedua) Rekrutmen politik tertutup adalah hanya memberikan kesempatan kepada orang-orang tertentu seperti kawan-kawan akrab penguasa, atau individu-inidividu yang mempunyai persamaan agama, daerah, etnis bahkan keluarga dari pihak penguasa.

\section{Metode Penelitian}

Jenis Penelitian

Menurut pendapat Bogdan dan Taylor (1975) dalam moleong (2002:3) menyatakan bahwa penelitian kualitatif adalah sebagai prosedur penelitian yang menghasilkan data deskriptif berupa kata-kata tertulis atau lisan dari orangorang dan perilaku yang dapat diamati.

Lokasi Penelitian

Yang menjadi Lokasi penelitian ini yaitu di Sekretariat PDIP Kabupaten Halmahera Utara karna peneliti telah mengenal lokasi dan subjek penelitian sehingga mememudahkan peneliti dalam memperoleh data yang sesuai dengan permasalahan penelitian.

Teknik Penentuan Informan

Informan merupakan orang yang dimanfaatkan untuk memberikan informasi tentang situasi dan kondisi latar belakang penelitian. Moleong mengatakan bahwa informan adalah orang-orang yang dipilih sesuai kepentingan permasalahan dan tujuan penelitian. Atau informan adalah orang yang memberikan informasi tentang data yang diinginkan peneliti berkaitan dengan penelitian yang sedang di laksanakan. Yang menjadi informan penelitian ini yaitu anggota legislative adalah Joel Wogono $\mathrm{SH} ., \mathrm{MH}$, sebagai calon dapil II, dan Ibu Inggrid Paparang SE, dari calon Dapil I, dan ketua DPD Kabupaten, Wakil Ketua, dan ketua Panitia seleksi calon legislatif. 
Teknik Pengumpulan Data

Dalam mengumpulkan data informasi yang dibutuhkan dalam penelitian ini digunakan beberapa teknik pengumpulan data yaitu data primer dan data sekunder.

\section{Data Primer}

Untuk mendapatkan data primer, dalam penelitian ini dilakukan dengan wawancara merupakan proses tanya jawab secara langsung yang ditujukan terhadap informan di lokasi penelitian dengan menggunakan panduan atau pedoman wawancara. Wawancara dengan melakukan komunikasi secara langsung untuk mendapatkan informasi secara mendalam dengan mengeksplorasi pertanyaan-pertanyaan pada informasi dengan mengacu pada panduan wawancara yang telah dirumuskan peneliti, sehingga data yang diperoleh dari hasil wawancara guna menganalisis data penelitian.

\section{Data sekunder}

Data sekunder merupakan semua data yang diperoleh melalui studi kepustakaan, pengumpulan data dari buku-buku referensi, jurnal, media yang sesuai dengan objek kajian penelitian.

\section{PEMBAHASAN}

\section{Persyaratan Calon Anggota Legislatif PDIP 2014}

Persyaratan adalah suatu kegiatan pemilihan dan penentuan pelamar yang di terima atau di tolak untuk di seleksi menjadi anggota yang berkualitas maupun kuantitas dari calon-calon yang akan di terimanya. Maka persyaratan sebagai berikut: a). Setiap bakal calon anggota DPR, DPRD Propinsi, dan DPRD kabupaten/kota harus memenuhi persyaratan sebagaimana diatur dalam pasal 51 Undang-undang Nomor 8 tahun 2012 tentang pemilu DPR, DPD, dan DPRD yaitu:Telah berumur 21 tahun atau lebihBertakwa kepada tuhan yang maha esa; b). Bertempat tinggal di wilayah Negara kesatuan Republik Indonesia; c). Cakap 
berbicara, membaca, dan menulis bahasa Indonesia; d). Berpendidikan paling rendah tamat sekolah menengah atas, madrasah aliyah, sekolah menengah kejuruan, madrasah aliyah kejuruan, atau pendidikan lain yang sederajat; e). Setia kepada pancasila sebagai dasar Negara, undang-undang dasar Negara republic Indonesia tahun 1945, dan cita-cita proklamasi 17 agustus 1945; f). Tidak pernah dijatuhi pidana penjara berdasarkan putusan pengadilan yang telah mempunyai kekuatan hokum tetap karna melakukan tindak pidana yang diancam dengan pidana penjara 5 tahun penjara atau lebih; g). Sehat jasmani dan rohani.

Jika dianalsis berdasarkan masalah penelitian maka dapat dijelaskan bahwa proses rekrutmen partai PDIP di dalamnya mengkuti persyaratan untuk menjadi calon anggota legislative berdasarkan Undang-Undang No 8 tahun 2012 tentang pemilu DPR, DPD, dan DPRD pada pasal 51 tentang bakal calon legislatif. Menurut Imawan (1992), seleksi anggota legislative harus memenuhi syaratsyarat kapabilitas, popularitas, dan ekseptabalitas. Ketiga syarat ini harus dipadukan, artinya seorang kandidat harus benar-benar memiliki ketiga syarat tersebut.

\section{Proses Penetapan Calon Anggota Legislatif PDIP}

Proses penetapan adalah hasil rapat partai yang sudah di putuskan bersama untuk menetapkan calon anggotanya. Ada beberapa proses penetapan untuk calon legislative Partai PDIP di tahun 2014 sebagai berikut: a) Proses penjaringan adalah tahapan penyeleksian yang paling pertama dariproses seleksi partai terhadap bakal calon anggota legislatif. DPC Partai memiliki tugas untuk merekrut bakal calon anggota legislatif.Setelah itu para calon mengisi formulir pendaftaran oleh bakal calon, hal inibagian dari persyaratan administrasi yang ada di partai; b) Proses penyaringan adalah tahapan penyeleksian yang kedua dari proses seleksi partai terhadap bakal calon anggota legislatif. Penyaringan ini dilakukan dengan wajib memperhatikan hasil dari psikotest, hasil penugasan partai, rekam jejak pengabdian di partai dan masyarakat, serta hasil tes bebas narkoba dan hasil pemahaman ideologi di partai. Proses ini berlaku untuk seluruh bakal calon anggota legislatif dari PDI Perjuangan; c) Proses penugasan 
dan penetapan adalah tahapan penyeleksian yang ketiga dariproses seleksi partai terhadap bakal calon anggota legislatif. Penugasan yangdiberikan oleh partai kepada bakal calon anggota legislatif untuk melaksanakantugas partai di daerah pemilihan masing-masing sesuai dengan tingkatannya, danuntuk dinilai kemampuannya dalam memenangkan pemilu; e) Penetapan nomor urut calon dilakukan dengan mempertimbangkan kualitas calon di dalam melaksanakan tugas-tuganya sebagai calon anggotalegislatif.

Dengan demikian Caleg yang memiliki kualitas lebih, dapat menempati nomor urut prioritas di dalam suatu daerah pemilihan. Contohnya ketua partai , sekretaris dan bendahara DPC Partai hanya mendapatkan hak untuk ditempatkan pada nomor prioritas dalam hal ini seluruh ketentuan di dalam penjaringan dan penyaringan dapat dipenuhi. Proses penetapan harus mengikuti aturan yang sudah di tetapkan oleh partai PDIP, dan khususnya Partai PDIP tidak membedabedakan jabatan atau kedudukan sebagai calon anggota legislatif.

Menurut Richard.S Katz dan William Crotty kriteria untuk menetapkan calon antara lain yaitu: a) Faktor usia, dimana seorang calon haruslah memiliki usia yang cukup yakni 21 tahun untuk dapat dicalonkan menjadi anggota legislatif. usia adalah hal yang penting karena dapat menentukan tingkat analisa seseorang dalam menghadapi masalah. Biasanya faktor usia juga dapat mengukur kematangan dan pengalaman seseorang dalam masyarakat; b) Pendidikan, yaitu seorang calon anggota legislatif harus mempunyai tingkat pendidikan yang bagus minimal sarjana agar calon tersebut dapat memahami dan mengatas masalah-masalah sosial yang terjadi di masyarakat.

\section{Kendala Dalam Proses Rekruitmen Politik Partai PDIP}

Salah satu penyebab terjadinya kendala dalam proses rekruitmen adalah tidak diketahuinya secara pasti kebutuhan pegawai oleh perekrut serta kurang mempunyai pengalaman menilai calon pegawai. Untuk menghindari kelemahanKelemahan itu maka seorang perekrut haruslah mengerti bagaimana jenis pendidikan, pengalaman dan ketrampilan dibutuhkan untuk setiap pekerjaan. 
Sebelum program rekruitmen dilakukan lebih jauh harus di lihat motivasi, tipe/bakat atau karasteristik dari masa jabatan minimum dari kandidat yang dibutuhkan sebelum dilakukan pengisian posisi dalam suatu organisasi, dengan kata lain petugas-petugas yang menangani kegiatan rekruitmen secara menyeluruh dan menangani kegiatan seleksi termasuk wawancara diwajibkan memiliki penguasan pengetahuan sabagai berikut; a) Memahami organisasi ditempat dia bekerja; b) Memahami karasteristik para pegawai atau calon pegawai dari berbagai tingkatan; c) Ketrampilan dan studi banding untuk melakukan seleksi; d) Memahami cara untuk menempatkan kandidat yang tepat untuk suatu jabatan. Ada beberapa kendalah dalam proses rekruitmen partai politik PDIP yaitu pertama pada masalah nomor urut calon legislative. Disini ada calon legislative yang menginginkan nomor urut kecil dan Kedua, ada calon legislative yang memintah daerah pemilihan (Dapil) karna merasa lebih bagus di daerah yang diinginkan oleh calon legislative bukan yang ditetapkan oleh ketua DPC, ketiga, sulitnya mendapatkan $30 \%$ keterwakilan perempuan pada calon legislative di partai PDIP.

Hasibuan (2006:52-53) menyebutkan dewasa ini cara seleksi dikenal dengan dua metode yaitu metode ilmiah dan non ilmiah yaitu a) Metode ilmiah adalah seleksi yang dilakukan berpedoman kepada kriteria dan standar-standar tertentu; b) Non ilmiah adalah seleksi yang dilaksanakan dengan tidak didasarkan pada criteria dan standar tertentu, melainkan hanya berdasarkan kriteria saja.

\section{Faktor Perbedaan Kursi Legislatif Tahun 2009 Dan 2014 PDIP}

Faktor perbedaan kursi terjadi yaitu perbuatan mensejajarkan sesuatu atau beberapa objek dari Pembanding. Dari perbedaan ini dapat di peroleh persamaan-persamaan dan perbedaan-perbedaan dari objek satu dengan objek lain. Faktor perbedaan kursi legislative menjadi sangat ketat sejalan dengan seleksinya calon-calon baru oleh partai politik seperti halnya faktor perbedaan kursi legislative di tahun 2009 dan 2014 hasilnya berbeda. Ditahun 2009 partai PDIP mendapatkan 3 (tiga) kursi, sedangkan ditahun 2014 partai PDIP hanya mendapatkan (2) kursi, disebabkan karena adanya kesalahan pada petugas dapil 
III yang tidak bekerja maksimal. serta lemahnya petugas partai di tingkat bawah. Oleh sebab itu, partai politik PDIP harus memberikan pembinaan atau arahanarahan kepada kader partai agar bisa menjadi calon legislative yang berintegritas baik.

Norris (1995) pernah menjelaskan pentingnya politik ini berlandaskan pada prinsip demokrasi, keadilan, efisien dan efektif.prinsip demokrasi menekankan pada kesempatan yang sama bagi individu dari berbagai latar belakang baik di tingkat nasional maupun lokal. Jadi tidak hanya mengedepankan garis keturunan.

\section{Penutup}

\section{Kesimpulan}

Dari pembahasan diatas, mengenai rekruitmen partai politik dalam penetapan calon legislatif Tahun 2014 Kabupaten Halmahera Utara, penulis akan menyimpulkannya sebagai berikut:

Pertama: Persyaratan calon anggota legislatif mengikuti peraturan perundangundangan partai politik namun juga sangat penting setiap calon telah memiliki elektabilitas dan popularitas yang tinggi serta dikenal banyak orang sehingga menjadi modal politik dan modal sosial setiap calon guna mendapat suara terbanyak pada pemilihan legislative. Metoda rekrutmen calon legislative cabang PDIP 2014 telah mengikuti aturan yang berlaku di internal partai PDIP.

Kedua: Proses penetapan calon anggota legislatif yaitu harus mengikuti beberapa tahap kemudian di tahap terakhir yaitu penetapan calon dilakukan melalui rapat kerja partai, dalam hal ini merupakan keputusan yang diambil berdasarkan suara terbanyak.

Ketiga:perbedaan kursi legislative tahun 2009 dan 2014 adalah kesalahan di petugas partai serta struktur partai yang bekerja tidak maksimal. Akibatanya perolehan suara dan keterpilihan calon dari PDIP ditahun 2014 mengalami penurunan yang sangat signifikan dibandingkan dengan keterpilihan calon di 
tahun 2009. Secara kelembagaan perlu diatur kembali manajemen kelembagaan partai politik cabang PDIP cabang Halmahera Utara dan metoda rekrutmen calon legislative perlu diperketat dalam penjaringan calon.

\section{Saran}

Berdasarkan hasil penelitian, Maka akan di sampaikan beberapa saran yang mungkin dapat menjadi bahan pertimbangan bagi Partai Politik dalam Penetapan Calon Anggota legislatif di Kabupaten Halmahera Utara.

Pertama: Dalam persyaratan seleksi harus lebih di perketaat sehingga berkasberkas calon yang lolos seleksi sudah melalui prosedur mekanisme yang di terapkan oleh partai politik.

Kedua: Proses penetapan calon legislatif harus memiliki keahlian serta kualitas hal ini untuk membuktikan kepada masyarakat bahwa partai PDIP mempunyai kualitas calon patut di pilih sebagai wakil rakyat.

Ketiga: Faktor perbedaan kursi legislatif2009 dan 2014,adalah sebuah kesalahan pada struktur partai yang tidak bekerja maksimal sehingga dapil III tidak mempunyai keterwakilan di kursi Legislatif. Oleh sebab itu diharapkan kepada partai PDIP supaya dapat memberikan Motifasi-motifasikhusus atau Pelatihananpelatihan kepada pegawai, sehingga dalam menjalankan tugas dan tanggungjawab benar-benar berdasarkan sesuai dengan aturan yang di tetapkan. 


\section{Daftar Pustaka}

Afan Gaffar. (2006). Politik Indonesia Transisi Menuju Demokrasi. Yogyakarta: Pustaka Pelajar.

Budiarjo, Miriam. 1989. Dasar-Dasar Ilmu Politik. (Jakarta: PT. Gramedia). Hal.159.

Bungin Burhan. 2010. Metode Penelitian Kualitatif. Pernada Media Group, Jakarta.

Cholisin, Dkk. 2007. Dasar-Dasar Ilmu Politik. Yogyakarta: UNY Press Hal 133.

Dwiyanto Agus. (2006). Reformasi Birokrasi Di Indonesia. Yogyakarta Gadjah Mada University Press.

Giovani Sartori .1955. Jenis Kepartaian Indonesia Tipe Parpol Indonesia Pemilu 19551971 Jenis-Jenis Partai Indonesia.

Haryanto, Dkk . (1997). Fungsi-Fungsi Pemerintahan. (Jakarta : Badan Pendidikan Dan Pelatihan Departemen Dalam Negeri)

Hasibuan, Malayu S.P. (2006). Manajemen, Dasar, Pengertian Dan Masalah. Jakarta : Bumi Aksara.

Imawan. 1992. Proses Pencalonan Dan Calon Dalam Pemilu Legislative. (Surabaya: Asosiasi Ilmu Politik Indonesia $1992 \mathrm{Hal} ; 12$ )

Kamaruddin Sahid . 2004. Partai Politik Di Pentas Reformasi: Refleksi Pemilu 1999 Untuk Pemilu 2004. Jakarta.

Moertopo Ali. (2000.) .Dasar-Dasar IImu Politik. Fakultasi Lmu Sosial,Universitas Negeri Yogyakarta

Max N Hagoapin (Ichlasul Amal) .1996. Teory Mutakhir Partai Politik. Yogyakarta : Tiara Mutiara, Hal: 96.

Morissan. (2005). Hukum Tata Negara Era Reformasi. Jakarta: Ramdina Prakarsa. Meleong, J.Lexi. 2005. Metode Penelitian Kualitatif. Bandung PT Remaja Rosdakarya Offset.

Roger H. Soltau, Jurnal: Dinamika Masyarakat (Partai Politik).2005.Hal;97

Rahman Bustami, Ms.Si. Ibrahim S,Si, Penyusun Proposal Penelitian.Jakarta 
Suharno, M.Si. 2004. Diklat Kuliah Sosiologi Politik. UNY:Rekruitmen Politik Pada Pemilu Legislatif 2009.Hal 177.

Sikmund Neumann, Mariam Budiardjo. Dasar-Dasar Ilmu Politik (Jakarta:PT,Gramedia Pustaka Utama). Macet Ke-10,H 160-162.

S. Katz, Richard Dan William Crotty. 2006.Hal:132, Handbook Of Party Politice. London: Sagen Publications

\section{Sumber-Sumber Lain:}

Undang-Undang Nomor 8 Tahun 2012 Tentang Pemilihan Umum Anggota Dewan Perwakilan Rakyat, Dewan Perwakilan Daerah, Dan Dewan Perwakilan Rakyat Daerah.

Httt:/Nasional.Sindonews.Com/Read/Profil-Partai-Demokrasi-IndonesiaPerjuangan. 